\title{
Managing soil fertility in organic farming systems
}

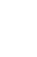

\author{
C.A.Watson ${ }^{1}$, D.Atkinson ${ }^{2}$, P.Gosling ${ }^{3}$, L.R. Jackson ${ }^{3}$ \& F.W. Rayns ${ }^{3}$
}

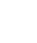

${ }^{1}$ Environment Division, SAC, Craibstone Estate, Aberdeen, AB21 9YA, UK

${ }^{2}$ SAC, West Mains Rd, Edinburgh, EH9 3JG, UK

${ }^{3}$ HDRA International Research Department, Ryton Organic Gardens, Coventry, CV8 3LG, UK

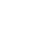

Corresponding author

Fax: + 441224 714591, e-mail: c.watson@ab.sac.ac.uk

\section{Abstract.}

Complex relationships exist between different components of the organic farm and the quantity and quality of the end products depend on the functioning of the whole system. As such, it is very difficult to isolate soil fertility from production and environmental aspects of the system. Crop rotation is the central tool that integrates the maintenance and development of soil fertility with different aspects of crop and livestock production in organic systems. Nutrient supply to crops depends on the use of legumes to add nitrogen to the system and limited inputs of supplementary nutrients, added in acceptable forms. Manures and crop residues are carefully managed to recycle nutrients around the farm. Management of soil organic matter, primarily through the use of short-term leys, helps ensure good soil structure and biological activity, important for nutrient supply, health and productivity of both crops and livestock. Carefully planned diverse rotations help reduce the incidence of pests and diseases and allow for cultural methods of weed control. As a result of the 
complex interactions between different system components, fertility management in organic farming relies on a long-term integrated approach rather than the more shortterm very targeted solutions common in conventional agriculture.

Keywords:

Organic farming, soil fertility, soil structure, crop nutrition, crop rotation, crop health

\section{INTRODUCTION}

Soil fertility is fundamental in determining the productivity of all farming systems. Soil fertility is most commonly defined in terms of the ability of a soil to supply nutrients to crops. Swift \& Palm (2000) however suggest that it is more helpful to view soil fertility as an ecosystem concept integrating the diverse soil functions, including nutrient supply, which promote plant production. This broader definition is appropriate to organic farming, as organic farming recognises the complex relationships that exist between different system components and that the sustainability of the system is dependent upon the functioning of a whole integrated and inter-related system (Atkinson \& Watson 2000).

Organic farming systems rely on the management of soil organic matter to enhance the chemical, biological, and physical properties of the soil, in order to optimise crop production. Soil management controls the supply of nutrients to crops, and subsequently to livestock and humans. Furthermore soil processes play a key role in suppressing weeds, pests and diseases. Figure 1 illustrates conceptually the complexity of the relationships between soil fertility and the different components within and outside the system that may influence it. One of the fundamental 
differences between management of organic and conventional systems is the way in which problems are addressed. Conventional agriculture often relies on targeted shortterm solutions e.g. application of a soluble fertiliser or herbicide. Organic systems, in contrast, use a strategically different approach, which relies on longer-term solutions (preventative rather than reactive) at the systems level. An example of this is the importance of rotation design for nutrient cycling and conservation and weed, pest and disease control (Stockdale et al. 2001).

Organic farming is the only sustainable farming system that is legally defined. Within the EU, crop and livestock products sold as organic must be certified as such under EC Regulation 2092/91 and 1804/99. In the UK, it is the role of the UK Register of Organic Food Standards (UKROFS) to implement this legislation. UKROFS licences a number of certification bodies, such as the Soil Association, to certify and inspect organic farms to ensure that organic production practices are followed. Although the regulations of the different bodies differ in detail they all aim to create an economically and environmentally sustainable form of agriculture with the emphasis placed on self-sustaining biological systems rather than on external inputs.

This paper explores how organic farmers and growers can utilise a range of management practices to maintain and develop soil fertility in order to achieve these wider goals.

\section{ORGANIC FARMING SYSTEMS}

The total value of UK organic production in 2000/01 was $£ 97$ million. Around $81 \%$ of certified organic land is rough grazing and permanent pasture, 9\% is temporary ley, 
$17.5 \%$ is in arable production and $2 \%$ is used for horticultural crops. There is an

2 increasing proportion of organic land in pasture, reflecting the relative ease of

3 converting extensive systems and greater benefits from area based support payments

4 (Soil Association 2001). Organic farming systems fall into similar categories as those

5 of conventional agriculture: mixed, livestock, stockless and horticultural. Berry et al.

6 (2002) (this volume) describe examples of some of these in more detail. The main

7 characteristics of these systems and their specific soil fertility challenges are

8 summarised below.

9

\section{Mixed systems}

Mixed systems are most commonly based on ley/arable rotations (see rotations section). Fertility is built during the ley phase, in which grazing and fodder production provide an economic return. The degree of integration of livestock and cropping will vary, depending on rotation, land type and livestock species. For example, sheep may graze turnips or vegetable residues over winter, while pigs are sometimes used instead of a plough to achieve the transition from ley to arable.

\section{Livestock systems}

In situations where it is undesirable or impractical to operate a rotation due to soil/land type, climate constraints or conservation issues, the use of long-term or permanent grassland is acceptable within the organic regulations. Management emphasis is, however, still on the maintenance of soil fertility through nutrient recycling, with minimal external inputs.

\section{Stockless systems}


The trend towards specialisation in conventional farming has led to large agricultural areas in Europe lacking grazing livestock, e.g. Eastern and South Eastern Denmark, Eastern Germany, and East Anglia in the UK (Høgh-Jensen 1999). The infrastructure costs associated with establishing livestock enterprises on farms wishing to convert from a conventional stockless system to mixed organic agriculture are frequently prohibitive (Lampkin 1990) and so the area of organic land farmed using stockless organic systems is increasing (Mueller \& Thorup-Kristensen 2001). The greatest challenge for stockless organic farming is management of the nutrient supply. Forage legumes are of no direct economic benefit in stockless systems (other than for setaside payments), so there is greater emphasis on alternative fertility building strategies, such as the use of green manures, grain legumes and the import of manures, composts and other acceptable fertilisers. These types of organic system are relatively recent and further development of suitable fertility building strategies is required.

\section{Horticultural systems}

The term horticulture covers a wide range of systems from field vegetable production to fruit and protected cropping (glasshouse/polytunnels). Intensive organic horticultural production systems are often the most dependent on imported nutrients. Many of the fruit and vegetables grown have a high demand for major and minor nutrients and additionally are susceptible to many pests and diseases (Toosey 1983). Combined with the fact that these systems frequently include several crops within one growing season, the maintenance of soil fertility is a major concern in these intensive systems. Organic standards recognize the difficulties of this type of production and permit rotations which, although there are still restrictions, rely on external inputs to maintain crop production (UKROFS 2001). It is difficult to maintain fertility by the 
use of rotations in perennial crops such as fruit, and in protected cropping where it is uneconomic to grow fertility building crops. Development of organic production in both of these systems is still at an early stage and development of both associated management techniques and standards is ongoing.

\section{USING CROP ROTATIONS TO MANAGE SOIL FERTILITY}

Crop rotation is a system where different plants are grown in a recurring, defined sequence. Crop rotations, including a mixture of leguminous 'fertility building' and cash crops, are the main mechanism for nutrient supply within organic systems. Rotations can also be designed to minimise the spread of weeds, pests and diseases (Altieri 1995). The development and implementation of well-designed crop rotations is central to the success of organic production systems (Lampkin 1990; Stockdale et al. 2001).

Organic rotations are divided into phases that increase the level of soil nitrogen and phases that deplete it (Altieri 1995). The nitrogen building and depleting phases must be in balance, or show a slight surplus, if long-term fertility is to be maintained (See Berry et al. 2002 and Watson et al. 2002 this volume). This type of rotation provides the basis for forward planning of nitrogen supply, necessary in the absence of soluble nitrogen fertiliser. In UK conditions the fertility building phase of the rotation usually takes the form of a ley, from one to five or more years in length, which incorporates a legume usually in combination with grass (Lampkin 1990). Atmospheric nitrogen fixed by the legume-rhizobium symbiosis is made available to subsequent cash crops when the ley is incorporated and the nitrogen mineralised through the action of soil micro organisms. 
2 The ratio of ley to arable will be determined by both the system (stocked or stockless)

3 and the soil type, being lower on nitrogen retentive soils and higher on un-retentive

4 (sandy) soils. A typical rotation on a mixed organic farm with a three-year grass and 5 clover ley will support two or three years of arable cropping (Lampkin 1990). This may be extended by including a nitrogen-fixing cash crop, such as beans, or by including a short period of nitrogen fixing green manure such as vetch between cash crops (Stockdale et al. 2001). In order to make maximum use of the large quantity of nitrogen released following ley incorporation; crops with a high demand for nitrogen, such as winter wheat or potatoes, are usually grown at the start of the cropping phase (Lampkin 1990). The amount of $\mathrm{N}$ released decreases with time following incorporation of the ley (Whitmore et al. 1992) thus spring sown cereals are often placed later in the arable phase of the rotation due to their lower $\mathrm{N}$ demand (Taylor et al. 2001). As with conventional agriculture, the primary limiting nutrient in organic systems is nitrogen (N) (Stockdale et al. 1995; Torstensson 1998). Yields of arable crops under organic management vary from as little as $50 \%$ to more than $95 \%$ of those in conventional agriculture, depending on the crop (Lampkin \& Measures 2001; Nix 2001; SAC 2000). The large shortfall in cereal yields is linked to the difficulty of managing soils to synchronise $\mathrm{N}$ mineralization with the period of maximum $\mathrm{N}$ demand (Stockdale et al. 1992). This is one of the greatest challenges faced by organic farmers (Willson et al. 2001).

Incorporation of leys carries with it a high risk of nitrate loss by leaching. Spring incorporation prior to spring cropping, where possible, has been shown to minimise leaching loss (Watson et al. 1993; Djurhuus \& Olsen 1997). Other factors such as 
grazing intensity and sward composition have also been shown to be important in determining the quantity and pattern of $\mathrm{N}$ release following ley incorporation (Davies et al. 2001).

Crop rotation also modifies the physical characteristics of the soil both directly and indirectly. The accumulation of organic matter during the ley phase plays a major direct role in soil structure formation (Clement \& Williams 1967; Grace et al. 1995). This results from the production of organic binding agents, such as polysaccharides, by microorganisms breaking down organic matter, and the enmeshing effects of the clover and grass roots and fungal hyphae (Wild 1988; Breland 1995). Conversely, soil organic matter and aggregate stability decline during the arable phase (Tisdall \& Oades 1982). The architectural characteristics of the root systems of different crops included in the rotation also influence soil structure formation (e.g. Chan \& Heenan 1991). Indirectly, the timing and use of different cultivation techniques and manure application at different points in the rotation influence soil structure.

Rotation design modifies both the size and activity of the soil microbial biomass. Indicators of biomass activity such as basal respiration and enzymatic activity suggest that there is a more active microbial biomass associated with grass-clover leys than with arable cropping (Watson et al. 1996; Haynes 1999), which is in turn linked to the decomposition of organic matter and nutrient mineralization (Haynes 1999). An active soil microbial biomass may also reduce the incidence of organisms deleterious to crop health (Hornby 1983). Currently the possibilities for manipulating individual components of the soil microbial biomass using agricultural practices are limited by our understanding of the functional significance of different organisms or groups of 
organisms. Knowledge of the impact of management practices on some beneficial organisms e.g. Arbuscular Mycorrhizal (AM) fungi is increasing. The beneficial effects of AM fungi, including improved crop nutrition, reductions in soil borne disease and improved soil structure,are liable to be stimulated in organic systems (Bethlenfalvy \& Lindermann 1992; Mäder et al. 2000). Fallow periods (Douds et al. 1997), cultivation (McGonigle \& Miller 2000) and the inclusion of non-mycorrhizal crops within the rotation (Karasawa et al. 2001) can reduce survival and effectivity of AM fungi.

Rotations are the primary means of controlling weeds, pests and diseases in organic farming. The use of the term 'appropriate rotation' in the UKROFS Standards (UKROFS 2001) implies that continuous monoculture is unacceptable due to the likely increased pressure from weeds, pests and diseases as well as difficulties of maintaining soil fertility. It has been demonstrated that soil borne pathogens are influenced by rotation length, with reduced disease levels associated with longer gaps between susceptible crops (Clark et al. 1998). Several soil fertility-related factors may contribute to the control of soil borne diseases, including increased soil microbial activity, leading to increased competition, parasitism and predation in the rhizosphere (Jawson et al. 1993; Workneh \& van Bruggen 1994; Knudsen et al. 1995). In general, organic systems are characterised by a diversity of crops in the rotation that improves the potential for cultural control of pests and diseases (Altieri 1995). Soil fertility management can also affect the susceptibility of crops to pests and diseases. For example, the relationship between mineral-nutrient content of crops and pest susceptibility is well documented (Dale 1988). Phelan et al. (1995) demonstrated for the first time that soil organic matter management history was related to the 
susceptibility of crops to the above ground pest Ostrinia nubilalis (European corn borer).

Growing a range of crops with different physiological attributes, sowing and harvest dates offers opportunities for cultivation and mechanical weed controlling operations to be undertaken at different times helping to prevent particular species from becoming a problem (Liebman \& Davis 2000). (See also section on cultivations). The proportion of ley within the rotation has also been shown to affect weed populations and the weed seed bank with weed problems declining as proportion of ley increases (Davies et al. 1997). Roots of some plants exude chemicals that deter potential competitors from growing in their vicinity through inhibition of germination and/or growth and the effects can continue after the incorporation of the inhibitive plant. This effect, known as allelopathy, is exhibited by both crop plants such as rye, vetch and triticale and weed species e.g Stellaria spp. (Barnes and Putnam, 1986; Teasdale 1988; Inderjit \& Dakshini 1998). Although there may potentially be negative effects of allelopathy on crop production, e.g. when there is inhibition of the germination of crop seedlings, there is a need to understand allelopathic effects in more detail as they can potentially be manipulated to advantage in organic systems (Olofsdotter 1999).

\section{Fertility building crops}

Legume based leys are the principle fertility building crops in temperate organic systems. In mixed systems white clover-grass leys are most common. Red clover is also frequently produced, both grown alone or with grass, and used for silage or as a green manure. Other legumes, grown either as fodder or as green manures, may be used in the shorter term or under particular soil or climatic conditions. These include 
other types of clover, lucerne, vetches, lupins and trefoils. Poutala et al. (1994) and Mueller \& Thorup-Kristensen (2001) have illustrated the potential of short-term leguminous green manures crops in stockless systems.

Predicting the actual amount of nitrogen fixed is notoriously difficult as it depends on many factors including legume species and cultivar, proportion of legume in the ley, management, weather conditions and the age of the ley (Ledgard \& Steele 1992; Watson et al. 2002 (this volume)). White clover-grass leys can fix up to $250 \mathrm{~kg} \mathrm{~N}$ ha $^{-1} \mathrm{yr}^{-1}$ (Kristensen et al. 1995), red clover leys up to $240 \mathrm{~kg} \mathrm{~N} \mathrm{ha}^{-1} \mathrm{yr}^{-1}$ (Schmidt et al. 1999) and lucerne up to $500 \mathrm{~kg} \mathrm{~N} \mathrm{ha}^{-1} \mathrm{yr}^{-1}$ (Spiertz \& Sibma 1986). Field beans have been estimated to fix up to approximately $200 \mathrm{~kg} \mathrm{~N} \mathrm{ha}^{-1} \mathrm{yr}^{-1}$ (van Kessel \& Hartley 2000). In terms of increasing soil nitrogen, grain legumes are of limited value since only $50 \%$ of their $\mathrm{N}$ requirement is derived from fixation (compared with $>80 \%$ in forage legumes) and much of the fixed $\mathrm{N}$ is removed in the grain harvest. This can sometimes result in net removal of nitrogen from the soil (van Kessel \& Hartley 2000).

The importance of crop and varietal selection

Crop choice is liable to reflect a number of different factors, such as previous experience of the farmer, soil type and climate constraints, markets and labour availability. The UKROFS standards (UKROFS 2001) require an appropriate multiannual rotation including legumes (see section Fertility Building Crops) and crops with differing rooting depths. The use of crops with different rooting depths occurs between crops within the rotation and within individual crops, e.g. forage herbs are 
commonly mixed with several varieties of clover and grass to provide different sward structures both above and below ground.

The inclusion in a rotation of green manures or cover crops can considerably increase the efficiency with which nitrogen is used. Non leguminous plants that grow vigorously over the winter period, such as grazing rye (Secale cereale) immobilize soil nitrogen that would otherwise be leached over winter (Wyland et al. 1995). This nitrogen is subsequently made available after incorporation by mineralization. Careful attention to the timing and method of incorporation of the cover crop can synchronize mineralization with periods of high crop demand (Hu et al. 1997; Rayns et al. 2000). One of the primary difficulties in designing rotations for organic farming is the complexity of managing soil fertility for multiple aims. For example, although the incorporation of green manures/cover crops can have beneficial effects on nitrogen management there may be associated diseases risk, for example, plant pathogens with a saprophytic phase such as Rhizoctonia solani can multiply in plant debris (Weinhold 1977). In contrast green manures and cover crops have also been shown to have potential for controlling diseases in vegetable crops (Abawi \& Widmer 2000).

Selection of modern crop varieties has generally taken place under high inputs of both fertilisers and pesticides. Conditions of zero $\mathrm{N}$ application in conventionally managed soils do not accurately represent soils managed organically, and thus modern conventionally selected breeds are unlikely to have optimal characteristics for organic systems. The yield penalty associated with organic production of crops such as wheat and barley, which have been bred intensively, is greater than for crops such as oats and triticale, which have undergone relatively little selective breeding. Foulkes et al. 
1 (1998) have found that modern varieties of winter wheat bred and tested with large

2 amounts of fertilizer $\mathrm{N}$ were to some extent less efficient at utilising soil $\mathrm{N}$ than older

3 varieties. Below ground characteristics such as rooting depth, root architecture and

4 root length are likely to be more important in organic systems, where available soil

5 nutrients may be limited (Atkinson et al. 1995). These characteristics have as yet

6 received little attention in breeding programmes. The ability of varieties to form

7 effective associations with AM fungi may also be important for crop nutrition and

8 disease resistance. Hetrick et al. (1992) demonstrated that modern cultivars displayed

9 less consistent and smaller growth responses to AM symbionts than old hexaploid wheat landraces and Hetrick et al. (1993) showed that cultivars released after 1950 have reduced dependance on AM fungal symbiosis.

Although conventional crop breeding has not produced varieties with nutrient acquisition characteristics that suit organic systems it has, to some degree, addressed resistance to pests and disease. For instance, NIAB recommended lists of cereals include varieties resistance to fungal diseases (NIAB 1996). 
organic systems but is less common in arable crops (Lampkin 1990). Several effective intercrop combinations of cereals and legumes have however been developed demonstrating that intercropping offers the opportunity to increase the use of symbiotically fixed nitrogen without compromising grain yield (Jensen 1996; Bulson et al. 1997). Undersowing of clover into cereals is a common practice for establishing leys (Taylor et al. 2001). Studies of intercropping of vegetables and fertility building crops have indicated that competition between the crop and the legume can be a major problem (Carruthers et al. 1997, Lotz et al. 1997). The understorey crop must be controlled by mowing and/or cultivation techniques and the cash crop must be more widely spaced than normal. There is a need to develop effective management strategies and crop combinations for all organic systems, but particularly stockless systems, in order to minimise the use of unproductive fertility building phases. Before intercropping is more widely accepted in these systems, the economic viability of intercropping requires more careful analysis (Theunissen 1997).

\section{Using cultivations within rotations}

Cultivation has a number of purposes, including incorporation of manures and crop residues and weed and disease control, as well as preparation of a seedbed for crops and for remediation of damaged soil structure caused by trafficking (Wild 1988). The choice of cultivation type will depend on both the principle aim and the soil type. Organic systems tend to utilise shallow rather than deep ploughing, as this retains crop residues near the soil surface, where they break down more rapidly and where most rooting occurs, while achieving sufficient aeration (Lampkin 1990, Lampkin \& Measures 1999). Cultivation itself leads to an increase in nutrient availability, particularly $\mathrm{N}$, as microbial activity is stimulated and organic matter breakdown 
1 occurs (Balloni \& Favalli 1987; Torbet et al. 1998; Silgram \& Shepherd 1999).

2 Mechanical weed control can thus provide a mid-season boost to crops by stimulating

3 mineralization although at other times additional stimulation of mineralization may

4 cause losses by leaching or denitrification. Intensive cultivation to control weeds may

5 also be counterproductive if soil compaction occurs (Liebman \& Dyck 1993), or

6 where weeds provide a habitat for beneficial insects or a mycorrhizal bridge between

7 crops (Atkinson et al. 2002).

8

\section{MANAGING CROP RESIDUES}

Crop residues can be an important source of nutrients to subsequent crops. It is well documented that different quantities of $\mathrm{N}, \mathrm{P}, \mathrm{K}$ and minor nutrients are removed from, and returned to, the soil depending on the crop species concerned (Wild 1988; Sylvester-Bradley 1993). The quantity and quality of crop residues will clearly influence the build up of soil organic matter (Jenkinson \& Ladd 1981) and the subsequent availability and timing of release of nutrients to following crops (Jarvis et al. 1996). Cereal straw, for example, contains only around $35 \mathrm{~kg} \mathrm{~N}$ ha $^{-1}$ compared with more than $150 \mathrm{~kg} \mathrm{~N} \mathrm{ha}^{-1}$ for some vegetables residues (Rahn et al. 1992, Jarvis et al. 1996). Most available values for nutrient contents of crop residues are from conventional agriculture and $\mathrm{N}$ limitation in organic systems means that crop residues are likely to be lower in N (Berry et al. 2002 this volume) and other nutrients (Watson et al. 2002 this volume). Residues also contain variable amounts of lignin and polyphenols, which influence decomposition and mineralization rates (Jarvis et al. 1996; Vanlauwe et al. 1997). Incorporation of $\mathrm{N}$ rich, low $\mathrm{C}: \mathrm{N}$ ratio residues leads to rapid mineralization and a large rise in soil mineral $\mathrm{N}$ (Rahn et al. 1992), while residues low in $\mathrm{N}$ such as cereal straw can lead to net immobilization of $\mathrm{N}$ in the short 
to medium term (Jenkinson 1985; Aulakh et al. 1991). The latter can be advantageous in preventing $\mathrm{N}$ leaching between crops (Jenkinson 1985; Nicholson et al. 1997). The inclusion of crops with a diverse range of $\mathrm{C}: \mathrm{N}$ ratios can help to conserve $\mathrm{N}$ within the system and, compared with monocropping, has the potential to increase the capacity of the soil to supply $\mathrm{N}$ in synchrony with crop demand (Drinkwater et al. 1998; Sanchez et al. 2001). Mixing residues of differing quality also has potential to synchronize mineralization with crop demands (Handayanto et al. 1997) though the practicalities of this on a farm scale are questionable.

\section{MANAGING MANURES AND SUPPLEMENTARY NUTRIENTS}

In addition to symbiotic $\mathrm{N}$ fixation and atmospheric deposition, nutrients may be brought in to the organic system in imported animal feeds, manures, composts and permitted fertilisers, such as rock phosphate (UKROFS 2001). The nature and quantity of imported nutrients will depend on the system and the soil type. Watson et al. (2002) (this volume) highlight the reliance on bought-in feed and bedding on organic dairy farms and purchased manure in organic horticultural systems.

Animal manures are the most common amendments applied to the soil. On mixed and livestock farms they are an important currency for re-distributing nutrients as it is important to ensure that fertility is not built in some fields at the expense of others. Manure use should be planned with regard to both farm system and field nutrient budgets (see Berry et al. 2002, this volume). Organic manures are traditionally applied to silage and root crops although it may be more beneficial to apply them to cash crops. Manure management within the rotation has been shown to have large effects on both yield and product quality, including protein levels in cereals (Stein- 
Bachinger 1996; Frederiksson et al. 1997). The possibility of using manures more profitably on cash crops is discussed in more detail by Berry et al. (2002) (this volume). Manures from non-organic livestock production may be brought onto the holding but there are restrictions (e.g. it must originate from an 'ethical' source and the animals producing it must not have been fed on a diet containing Genetically Modified Organisms (GMO’s)).

The quantity of nutrients in manures varies with type of animal, feed composition, quality and quantity of bedding material, length of storage and storage conditions (Dewes \& Hunsche 1998; Shepherd et al. 1999). A typical application of $25 \mathrm{t} \mathrm{ha}^{-1}$ of farmyard manure from housed organic cattle will contain $150 \mathrm{~kg}$ of N, $35 \mathrm{~kg}$ of P and $140 \mathrm{~kg}$ of K (Shepherd et al. 1999). In organic systems it is particularly important to conserve manure nutrients for both economic and environmental reasons. Manure handling, storage and composting has been widely studied in organic systems (e.g. Hansen 1995). Composting is recommended in organic farming as a management tool for controlling weeds, pests and diseases. True composting of manures, i.e. aerobic decomposition at temperatures of around $60^{\circ} \mathrm{C}$, results in fundamental physical and chemical changes, causing a significant reduction in nutrient availability, particularly of nitrogen. Composted manure thus has a more long-term role in building soil fertility, and has been shown to be more effective in building soil microbial biomass and increasing activity than uncomposted manure (Fließbach \& Mäder 2000). Composts have been show to reduce disease severity (Kim et al. 1997; Abawi \& Widmer 2000). In addition to composts made from on-farm materials, composts may originate from commercial sources and include materials from parks and gardens (green waste compost), pack house wastes and food industry wastes. Although such 
material fits well with the ethical basis of organic farming there may be increasing problems with contamination with residues from GMO's.

In order to balance the offtake of specific nutrients there are a number of mineral nutrient sources acceptable in organic systems although their use is permitted only where the need can be demonstrated to the certifying body (for example by soil analysis or by presentation of a nutrient budget). Amendments include rock phosphate, rock potassium, magnesium rock and gypsum. Products such as rock phosphate release nutrients over a period of years rather than weeks (Rajan et al. 1996) and thus their use is planned to build fertility in the longer-term. Trace elements may also be applied, with approval, if they are necessary. The use of lime to maintain pH levels is also acceptable (UKROFS 2001).

\section{SOIL FERTILITY AND LIVESTOCK IN ORGANIC FARMING}

Within organic systems both the influence of livestock on soil fertility and the influence of soil fertility on livestock nutrition and health are important management considerations (See Figure 1). Livestock influences soil fertility by two major routes, through physical effects associated with trampling and also through the removal and return of nutrients in dung and urine. Stocking rate in organic systems is limited by a maximum application rate of $170 \mathrm{~kg} \mathrm{~N} \mathrm{ha}^{-1} \mathrm{yr}^{-1}$ (UKROFS 2001) over the farm as a whole. Compared with conventional systems the lower stocking rates and mixed grazing systems common in organic farming (Lampkin \& Measures 1999) may help to minimise the effects of grazing on soil compaction. Bannerjee et al. (2000) suggested that pasture management could also influence soil microbial biomass, with lower stocking rates promoting both higher biomass $\mathrm{C}$ and $\mathrm{N}$ mineralization potential. 
1 In forage based organic systems on soils naturally low in trace elements, livestock

2 health can be adversely affected by trace element deficiencies. Under known

3 deficiency conditions trace element supplementation is allowed within the organic

4 standards (UKROFS 2001). An alternative solution is the inclusion of forage herbs

5 such as chicory within organic swards; these are known to contain higher

$6 \quad$ concentrations of trace elements than many grasses (Belesky et al. 2001).

It is becoming increasingly clear that both livestock and manures can act as a conduit for environmental pathogens that survive in soils. Management practices can help to minimise the spread of pathogens via manure. Both composting of farmyard manure (Jones 1982) and anaerobic digestion of slurry (Kearney et al. 1993) have been shown to decrease pathogen viability. It has also been shown that earthworms can be beneficial in parasite control as they ingest eggs and larvae and carry them far enough below ground to prevent them maturing (Wells 1999). The effect of organic management practices on earthworms is discussed in Scullion (2002) (this volume).

\section{DECISION SUPPORT TOOLS}

Improving soil fertility in organic farming relies on improved understanding of the effects of management practices on soil fertility and also on improved technology transfer of research results into practice. This requires the provision of good on-farm advice by advisors who fully understand the complexity of managing soil fertility in organic farming systems. The development and widespread accessibility of appropriate tools to support decision-making is also important (Wander \& Drinkwater 2000). 
Soil analysis

As soil fertility management in organic systems is a longer term, more strategic process than in conventional systems, soil analysis and interpretation must be adapted to reflect this. Trends in soil nutrient and organic matter status are likely to be more important than snapshot analysis. There has been considerable discussion over whether different methods of soil analysis are required for organic farming. Conventional soil analysis for advisory purposes relies on the interpretation of the chemical extraction of different nutrient pools from the soil to predict nutrient release to crops (Edwards et al. 1997). This type of analysis is likely to be more difficult to interpret in organic than conventional systems where there is a much stronger reliance on biological processes for nutrient supply. There is much interest in the development of indicators of soil health and quality although little agreement over what these should be (Doran \& Zeiss 2000). Simple indicators of soil health would help organic farmers to solve problems on farm. Wander \& Drinkwater (2000) suggest that organic matter and organic matter dependent properties show most promise for supporting management decisions.

\section{Computer modelling}

Simple nutrient budgets are becoming widely used in organic farming by advisors and certification organisations to assist in the planning of organic crop rotations. Computer models for calculation of nutrient budgets are currently being developed in association with organic farming research programmes being funded by DEFRA and SEERAD. The use of nutrient budgets in organic systems is discussed more fully in Berry et al. (2002) and Watson et al. (2002) (this volume). One of the limitations of both nutrient budgets and more detailed nutrient cycling models such as WELL_N 
1 (Rahn et al. 2001) is the difficulty of predicting the soil processes which drive organic

2 systems, particularly mineralization and $\mathrm{N}$ fixation. Some of the more detailed models

3 of nutrient cycling and crop growth may however be useful in developing new and

4 efficient cropping systems for organic farming. For example, Baumann et al. (2001)

5 suggest that ecophysiological crop growth models could be used to maximise crop complementarity and thus design more effective intercropping systems.

\section{CONCLUSIONS}

Organic farming systems utilise highly complex and integrated biological systems to achieve their goal of sustainable crop and livestock production. Most, if not all, management practices used in organic systems affect more than one component of the system, for example, cultivation may be beneficial for weed control but may stimulate mineralization of nitrogen when the crop does not require it. Some soil management decisions, such as the choice between winter and spring incorporation of a ley, are likely to have important economic consequences as well as environmental ones. Thus the interaction between soil management practices and different aspects of production and environmental impact will continue to challenge the nature and development of organic farming in the future.

Large-scale organic production is still a relatively recent development and further development of fertility building strategies is warranted in all systems. This is particularly true with regard to the most efficient use of manures and the most appropriate types of ley and green manures. Fertility management in stockless arable, field vegetables, fruit and protected cropping is particularly challenging and requires development, both in terms of techniques and of organic standards. 
We gratefully acknowledge financial support from SEERAD and DEFRA.

\section{REFERENCES}

Abawi GS \& Widmer TL 2000. Impact of soil health management practices on soilborne pathogens, nematodes and root diseases of vegetable crops. Applied Soil Ecology 15, 37-47.

Altieri MA 1995. Agroecology: the science of sustainable agriculture. Intermediate Technology Publications, London UK.

Atkinson D Baddeley J Goicocchea N Green J Sanchez-Diaz M \& Watson CA 2002. AMF in low input agriculture. In: Mycorrhizal technology: From genes to Bioproducts - Achievements and hurdles in arbuscular mycorrhizal research, ed $\mathrm{H}$ Schuepp, Birkhauser Basel. (In press)

Atkinson D Watson CA Hooker JE \& Black KE 1995. Nutrient Conservation in Organic Crop Production Systems In: Soil Management in Sustainable Agriculture, eds HF Cook \& HC Lee, Wye College Press Ashford pp 54-60.

Atkinson D \& Watson CA 2000. The research needs of organic agriculture - distinct or just part of agricultural research? The BCPC Conference - Pests \& Diseases 2000, 151158.

Aulakh MS Doran JW Walters DT Mosier AR \&Francis DD 1991 Crop residue type and placement effects on denitrification and mineralisation. Soil Science Society of America Journal 55, 1020-1025.

Balloni W \& Favalli F 1987. Effects of agricultural practice on the physical, chemical and biological properties of soils. Part I Effect of some agricultural practices on the 
biological soil fertility. In: Scientific basis for soil protection in the EC eds H Barth \& P L’Hermite, Elsevier Applied Science London.

Bannerjee MR Burton DL McCaughey WP \& Grant CA 2000. Influence of pasture management on soil biological quality. Journal of Range Management 53, 127133.

Barnes JP \& Putnam AR 1986. Evidence for allelopathy by residues and aqueous extracts of rye. Weed Science 34, 384-390.

Baumann DT Bastiaans L \& Kropff MJ 2001. Competition and crop performance in a leek-celery intercropping system. Crop Science 41, 764-774.

Belesky DP Turner KE Fedders JM Ruckle JM 2001. Mineral composition of swards containing forage chicory. Agronomy Journal 93, 468-475.

Berry PM Stockdale EA Sylvester-Bradley R Philipps L Smith KA Lord EI Watson CA \& Fortune S 2002. N, P and K budgets for crop rotations on nine organic farms in the UK. Soil Use and Management (this volume)

Bethlenfalvy GJ \& Lindermann RG 1992. Mycorrhizae in sustainable agriculture. ASA Special Publication No54 Madison, Wisconsin.

Breland TA 1995. Green manuring with clover and ryegrass catch crops undersown in spring wheat: effects on soil structure. Soil Use and Management 11, 136-167.

Bulson HAJ Snaydon RW \& Stopes CE 1997. Effects of plant density on intercropped wheat and field beans in an organic farming system Journal of Agricultural Science, Cambridge 128, 59-71.

Carruthers SP Harris PM Tranter RB Jones S Miller FA Bennett RM Davies L Stopes CE Lennatsson M \& Rayns FW 1997. Organic herbage legume intercropping. Final report to MAFF Project CSA 2414. Reading University. 
1 Chan KY \& Heenan DP 1991. Differences in surface soil aggregation under six

2 different crops. Australian journal of Experimental Agriculture 31, 683-686.

3 Clark MS Ferris H Klobsky K Lanini WT van Bruggen AHC \& Zalom FG 1998.

4 Agronomic, economic and environmental comparison of pest management in

5 conventional and alternative tomato and corn systems in northern California.

$6 \quad$ Agriculture, Ecosystems and Environment 68, 51-71.

7 Clement CR \& Williams TE 1967. Leys and soil organic matter II. The accumulation

8 of nitrogen in soils under different leys. Journal of Agricultural Science, $9 \quad$ Cambridge 59, 133-138.

Dale D 1988. Plant-mediated effects of soil mineral stresses on insects. In: Plant stress-insect interactions, ed EA Heinrichs, Wiley New York pp 35-110.

Davies DHK Christal A Talbot M Lawson HM \& Wright GM 1997. Changes in weed populations in the conversion of two arable farms to organic farming. The BCPC Conference - Weeds pp 973-978.

Davies MG Smith KA \& Vinten AJ 2001. The mineralisation of nitrogen following ploughing of grass and grass-clover swards. Biology and Fertility of Soils 33, 423434.

Dewes T \& Hunsche E 1998. Composition and microbial degradability in the soil of farmyard manure from ecologically-managed farms. Biological Agriculture and Horticulture 16, 251-258.

Doran JW \& Zeiss MR 2000. Soil health and sustainability: managing the biotic component of soil quality. Applied Soil Ecology 15, 3-11.

Douds DD Galvez L Franke-Snyder M Reider C \& Drinkwater LE 1997. Effect of compost addition and crop rotation point upon VAM fungi. Agriculture, Ecosystems \& Environment 65, 257-266. 
1 Drinkwater LE Wagoner P \& Sarrantonio M 1998. Legume-based cropping systems

2 have reduced carbon and nitrogen losses. Nature 396, 262-265.

3 Djurhuus J \& Olsen P 1997. Nitrate leaching after cut grass/clover leys as affected by

$4 \quad$ time of ploughing. Soil Use and Management 13, 61-67.

5 Edwards AC Withers PJA \& Sims TJ 1997. Are current fertiliser recommendation 
Haynes RJ 1999. Size and activity of the soil microbial biomass under grass and arable management. Biology and Fertility of Soils 30, 210-216.

Hetrick BAD Wilson GWT \& Cox TS 1992. Mycorrhizal dependence of modern wheat culitvars, land races and ancestors. Canadian Journal of Botany 70, 20322040.

Hetrick BAD Wilson GWT \& Cox TS 1993. Mycorrhizal dependence of modern wheat culitvars and ancestors: a synthesis. Canadian Journal of Botany 71, 512518

Høgh-Jensen H 1999. The proportion of green fallow in stockless farming systems: grain $\mathrm{N}$ yield, $\mathrm{N}$ leaching and soil organic $\mathrm{N}$. In: Designing and testing crop rotations for organic farming, eds JE Olesen R Eltun MJ Gooding ES Jensen \& U Köpke, Danish Research Centre for Organic Farming Foulum pp 223-234.

Hornby D 1983. Suppressive soils. Annual Review Phytopathology 21, 65-85.

Hu S Grunwald NJ van Bruggen AHC Gamble GR Drinkwater LE Shennan C \& Demment MW 1997. Short-term effects of cover crop incorporation on soil carbon pools and nitrogen availability. Soil Science Society of America Journal 61, 901911.

Inderjit \& Dakshini KMM 1998. Allelopathic interference of chickweed, Stellaria media with seedling growth of wheat Triticum aestivum. Canadian Journal of Botany 76, 1317-1321.

Jarvis SC Stockdale EA Shepherd MA \& Powlson DS. 1996. Nitrogen mineralization in temperate agricultural soils: processes and measurement. Advances in Agronomy 57, 187-235. 
1 Jawson MD Franzlubbers AJ Galusha DK \& Aiken RM 1993. Soil fumigation within

2 monoculture and rotations - response of corn and mycorrhizae. Agronomy Journal $3 \quad 85,1174-1180$.

4 Jenkinson DS \& Ladd JN 1981. Microbial biomass in soil: measurement and turnover.

5 In: Soil Biochemistry Volume 5, eds EA Paul \& AD McLaren, Marcel Dekker

$6 \quad$ New York pp 415-471

7 Jenkinson DS 1985 How straw incorporation affects the nitrogen cycle. In: Straw,

8 soils and science, ed J Hardcastle, AFRC London pp 14-15.

Jensen ES 1996. Grain yield, symbiotic $\mathrm{N}_{2}$ fixation and interspecific competition for organic-N in pea-barley intercrop. Plant and Soil 182, 25-38.

Jones PW 1982. Waste and animal health. Public Health Engineering 10, 35-39.

Karasawa T Kasahara Y \& Takebe M 2001.Variable response of growth and arbuscular mycorrhizal colonization of maize plants to preceding crops in various types of soils. Biology and Fertility of Soils 33, 286-293.

Kearney TE Larkin MJ Frost JP \& Levett PN 1993. Survival of pathogenic bacteria during mesophilic anaerobic digestion of animal waste. Journal of Applied Bacteriology 74, 86-93.

Kim KD Nemec S \& Musson G 1997. Effects of composts and soil amandements on soil microflora and Phytophthora root and crown rot of bell pepper. Crop Protection 16, 165-172.

Knudsen IMB Debosz K Hockenhull J Jensen DF \& Elmholt S 1995. Suppressiveness of organically and conventionally managed soils towards brown foot rot of barley. Applied Soil Ecology 12, 61-72. 
1 Kristensen ES Hogh-Jensen H \& Kristensen IS 1995. A simple-model for estimation of atmospherically-derived nitrogen in grass-clover systems Biological Agriculture and Horticulture 12, 263-276.

$4 \quad$ Lampkin N 1990. Organic Farming. Farming Press Books Ipswich UK.

5 Lampkin N \& Measures M (eds) 1999. Organic Farm Management Handbook $3^{\text {rd }}$ 
Nicholson FA Chambers BJ Mills AR \& Strachan PJ 1997. Effects of repeated straw incorporation on crop fertilizer nitrogen requirements, soil mineral nitrogen and nitrate leaching losses. Soil Use and Management 13, 136-142.

Nix J 2001. Farm Management Pocketbook $32^{\text {nd }}$ Edition. Wye College London.

Olofsdotter M 1999. Allelopathy - a future component of weed management. Proceedings of the $16^{\text {th }}$ Danish Plant Protection Conference: Weeds. DJF-Rapport, Markbrug. No 9, 101-112.

Phelan PL Mason JF \& Stinner BR 1995. Soil fertility management and host preference by European corn borer, Ostrinai nubilalis (Hübner), on Zea mays L.: A comparison of organic and conventional farming. Agriculture Ecosystems and Environment 56, 1-8.

Poutala RT Kuoppamaki O Korva J \& Varis E 1994. The performance of ecological, integrated and conventional management systems in cereal cropping in Finland. Field Crops Research 37, 3-10.

Rahn C Mead A Draycott A Lillywhite R Salo T 2001. A sensitivity analysis of the nitrogen fertilizer requirement of cauliflower using the HRI WELL_N computer model. Journal Of Agricultural Science 137, 55-69.

Rahn CR Vaidyanthan LV \& Paterson CD 1992. Nitrogen residues from brassica crops. Aspects of Applied Biology 30, 263-270.

Rajan SSS Watkinson JH \& Sinclair AG 1996. Phosphate rocks for dirt application to soils. Advances in Agronomy 57, 77-159.

Rayns F Jackson L Lennartsson M \& Rahn C 2000. Winter cover crops; their relevance for organic horticultural production. Proceedings 13th International IFOAM Scientific Conference pp 199.

SAC 2000. The Farm Management Handbook 2000/2001, SAC Edinburgh. 
Sanchez JE Willson TC Kizilkaya K Parker E \& Harwood RR 2001. Enhancing the mineralizable nitrogen pool through substrate diversity in long term cropping systems. Soil Science Society of America Journal 65, 1442-1447.

Schmidt H Philipps L Welsh JP \& von Fragstein P 1999. Legume breaks in stockless organic farming rotations: nitrogen accumulation and influence on the following crops. Biological Agriculture and Horticulture 17, 159-170.

Scullion et al 2002 (this volume)

Shepherd MA Bhogal A Philipps L Rayns F Lennartsson M \& Pain B 1999 The environmental impacts of manure use in organic agriculture. Report to MAFF for project no. OF0161.

Silgram M \& Shepherd MA 1999. The effect of cultivation on soil nitrogen mineralisation. Advances in Agronomy 65, 267-311.

Soil Association 2001. Organic food and farming report 2001. Soil Association Bristol UK.

Spiertz JHJ \& Sibma L 1986. Dry-matter production and utilization in cropping systems with grass, lucerne and maize. 2. Nitrogen yield and utilization. Netherlands Journal Of Agricultural Science 34, 37-47.

Stein-Bachinger K 1996. Strategies to improve yield and crop quality by different distribution of limited amounts of farmyard and liquid manure applied to subsequent crops after grass-clover. Proceedings of the $3^{\text {rd }}$ meeting of Fertilization Systems in Organic Farming, Copenhagen pp 64-74.

Stockdale EA Lampkin NH Hovi M Keatinge R Lennartsson EKM MacDonald DW Padel S Tattersall FH Wolfe MS \& Watson CA 2001. Agronomic and Environmental Implications of Organic Farming Systems. Advances in Agronomy 70, 261-327. 
Stockdale EA, McKinlay RG \& Rees RM 1992. Soil nitrogen management and interactions with pests and diseases in organic farming. Aspects of Applied Biology 30, 387-392.

Stockdale EA Rees RM \& Davies MG 1995. Nitrogen supply for organic cereal production in Scotland. In: Soil Management in Sustainable Agriculture, eds HF Cook \& HC Lee, Wye College Press Ashford pp254-264.

Swift MJ \& Palm CA 2000. Soil fertility as an ecosystem concept: A paradigm lost or regained? In: Accomplishments and changing paradigm towards the $21^{\text {st }}$ Century.

Sylvester-Bradley R 1993. Scope for more efficient use of fertilizer nitrogen. Soil Use and Management 9, 112-117.

Taylor BR Watson CA Stockdale EA McKinlay RG Younie D \& Cranstoun D 2001.Current practices and future prospects for organic cereal production: survey and literature review. Research Review No. 45. HGCA.

Teasdale JR 1988. Weed suppression by hairy vetch residue. Proceedings, North East Weed Society 42, 72.

Theunissen J 1997. Application of intercropping in organic agriculture. Biological Agriculture \& Horticulture 15, 251-259.

Tisdall JM \& Oades JM 1982. Organic matter and water stable aggregates in soils. Journal of Soil Science 33, 141-163.

Toosey RD 1983. Arable Crops. In: The Agricultural Notebook, ed RJ Halley, Butterworths London pp 83-104.

Torbet HA Potter KN \& Morrison JE 1998. Tillage intensity and crop residue effects on nitrogen and carbon cycling in a vertisol. Plant and Soil 29, 717-727 
1 Torstensson G 1998. Nitrogen delivery and utilization by subsequent crops after

2 incorporation of leys with different plant composition. Biological Agriculture and

$3 \quad$ Horticulture 16, 129-143.

4 UKROFS (2001). UKROFS Standards for Organic Food Production. UKROFS

5 London.

6 Vanlauwe B Diels J Sanginga N \& Merckx R 1997 Residue quality and 7 decomposition: An unsteady relationship? In:Driven By Nature: Plant Litter 8 Quality and Decomposition eds G Cadish \& KE Giller, CAB International $9 \quad$ Wallingford UK pp157-166.

van Kessel C \& Hartley C 2000. Agricultural management of grain legumes: has it led to an increase in nitrogen fixation? Field Crops Research 65, 165-181.

Wander MM \& Drinkwater LE 2000. Fostering soil stewardship through soil quality assessment. Applied Soil Ecology 15, 61-73.

Watson CA Bengtsson H Løes A-K Myrbeck A Salomon E Schroder J \& Stockdale EA 2002. A review of farm-scale nutrient budgets for organic farms in temperate regions. Soil Use and Management (this volume)

Watson CA Fowler SM \& Wilman D 1993. Soil inorganic-N and nitrate leaching on organic farms. Journal of Agricultural Science, Cambridge 120, 361-369.

Watson CA Ritz K Younie D \& Franklin M 1996. Nitrogen and soil biomass dynamics in two crop rotations. Aspects of Applied Biology 47, 43-50.

Weinhold AR 1977. Population of Rhizoctonia solani in agricultural soils determined by a screening process. Phytopathology 67, 566-569.

Wells A 1999. Integrated parasite management for livestock. ATTRA, Fayeteville USA. 
Whitmore AP Bradbury NJ \& Johnson PA 1992. Potential contribution of ploughed grassland to nitrate leaching after ploughing. Agriculture Ecosystems and Environment 123, 39-49.

Willson TC Paul EA \& Harwood RR 2001. Biologically active soil organic matter fractions in sustainable cropping systems. Applied Soil Ecology 16, 63-76.

Wild A 1988. Russell's Soil conditions and plant growth. Longman Scientific \& Technical Harlow UK.

Willey RW 1979. Intercropping - its importance and research needs. Part 1. Competition and yield advantages. Field Crop Abstracts 32, 1-10.

Wolfe MS 1985. The current status and prospects of multiline and variety mixtures for disease resistance. Annual Review of Phytopathology 23, 251-273.

Wolfe MS 2001. Species and Varietal Mixtures. In: Organic cereals and pulses, eds D Younie BR Taylor, JP Welsh \& JM Wilkinson, Chalcombe Publications Lincoln UK pp 29-49.

Workneh F \& van Bruggen AHC 1994. Suppression of corky root of tomatoes in soils from organic farms, associated with soil microbial activity and nitrogen status of soil and tomato tissue. Phytopathology 84, 688-694.

Wyland LJ Jackson LE \& Schulbach KF 1995. Soil-plant nitrogen dynamics following incorporation of a mature ryegrass cover crop in a lettuce production system. Journal of Agricultural Science 124, 17-25. 
1 Figure 1 . The interactions between soil fertility and crop and animal productivity in 2 organic farming systems. 


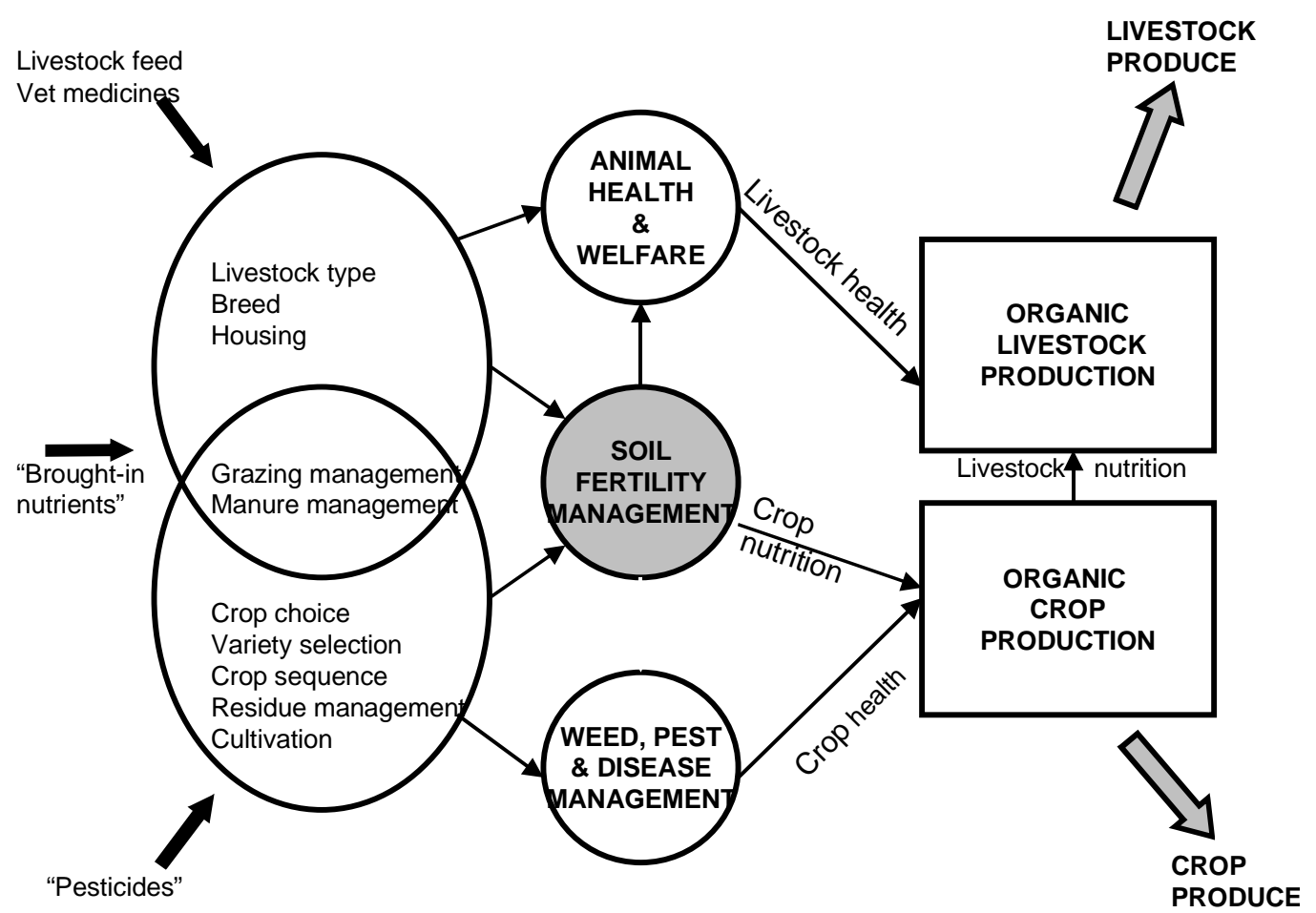

